\title{
Pengaruh Kualitas Sumber Daya Manusia dan Kualitas Anggaran Terhadap Kinerja Keuangan Daerah Yang Dimoderasi Dengan SIMDA Pada SKPD Kabupaten Buton Utara
}

\author{
Riawan \\ Universitas Muhammadiyah Ponorogo \\ Email: riawan13awan@gmail.com
}

\begin{abstract}
This study was conducted to examine the influence of human resources quality and budget quality on local government financial performance. In addition, this study was conducted to examine the influence of moderating variables Regional Management Information System on the relationship between human resources quality and budeget quality on local government financial performance. The number of population in the study are all the regional work units (SKPD) in North Buton Regency with totaling 34. The sampling using census techniques throughout the regional work units (SKPD) in North Buton Regency used a sample. Of the 34 questionnaires distributed, only 32 work units (SKPD) who returned the questionnaires. To test hypothesis using multiple linear regression analysis with the application program partial least square (PLS). The results showed that (1) Human resources quality have a positive significant effect on local government financial performance, (2) Budget quality have a positive significant effect on local government financial performance, (3) Regional Management Information System (SIMDA) have a positive significant effect in moderating the influence of human resources quality on local government financial performance, (4) Regional Management Information System (SIMDA) have a positive significant effect in moderating the influence of budget quality on local government financial performance.
\end{abstract}

Keywords: Human Resources Quality, Budget Quality, Regional Management Information System and Local Government Financial Performance

\section{PENDAHULUAN}

Dalam rangka penerapan kebijakan otonomi daerah pada dasarnya diarahkan untuk mendorong peningkatan kualitas pemerintah daerah dalam memberikan pelayanan kepada masyarakat secara lebih efektif dan efisien. Kedekatan organisasi pemerintah pada level daerah diharapkan lebih mampu menerima aspirasi riil masyarakat tentang pelayanan apa yang dibutuhkan. Oleh karena itu, diharapkan ada input yang diperoleh dalam rangka perencanaan pembangunan sehingga tidak ada kesenjangan antara perencanaan pembangunan yang dilaksanakan pemerintah baik program dan anggaran dengan kebutuhan riil masyarakat (Nordiawan, 2008).

Proses perencanaan pembangunan daerah perlu diimbangi dengan ketersediaan beberapa hal seperti: kualitas aparatur pemerintah, sumber daya baik sumber daya manusia maupun sumber dana. Berkaitan dengan hal ini, maka untuk mengukur tingkat pencapaian atas rencana yang ditetapkan dengan sasaran yang ingin dicapai perlu dilakukan evaluasi atas kinerja. Evaluasi kinerja bertujuan untuk mengukur sejauh mana kemampuan aparatur pemerintah dalam menjalankan 
kinerja organisasi pemerintahan. Melalui pengukuran kinerja akan nampak profesionalisme seorang pegawai dalam implementasi kinerja. Pengukuran kinerja digunakan sebagai dasar untuk melakukan penilaian kinerja yaitu untuk menilai sukses atau tidaknya suatu organisasi, program atau kegiatan. selaras dengan Greiling (2005) yang mengungkapkan bahwa salah satu kunci sukses dari pembaharuan dalam sektor publik adalah dengan melakukan pengukuran kinerja keuangan daerah.

Dalam mengelola keuangan dengan baik maka pemerintah daerah membutuhkan sumber daya manusia yang professional yang memiliki kualitas dan kompetensi tinggi terutama bagi yang duduk dalam jabatan, sebagaimana ditekankan pada pasal 17 ayat (2) UU Nomor 43 Tahun 1999, yaitu pengangkatan Pegawai Negeri Sipil dalam suatu jabatan dilaksanakan berdasarkan prinsip profesionalisme sesuai dengan kompetensi, prestasi kerja dan jenjang pangkat yang ditetapkan untuk jabatan tersebut. Sumber daya manusia dalam suatu organisasi merupakan penentu yang sangat penting bagi keefektifan berjalannya kegiatan didalam organisasi. Oleh karena itu dalam pengelolaan keuangan daerah yang baik, Satuan Perangkat Kerja Daerah (SKPD) harus memiliki sumber daya manusia yang berkualitas, yang didukung latar belakang pendidikan, sering mengikuti pendidikan dan pelatihan, dan mempunyai pengalaman di bidang keuangan (Wansyah, et.al, 2012 dan Gomes, et.al, 2013).

Penelitian kualitas sumber daya manusia terhadap kinerja keuangan daerah belum mendapatkan hasil penelitian yang konsisten. Hasil penelitian Gomes, et.al, (2013) menunjukkan bahwa kualitas sumber daya manusia berpengaruh positif signifikan terhadap kinerja keuangan. Sumber Daya Manusia yang memiliki kualitas yang tinggi seperti latar belakang pendidikan, dan pengalaman maka dapat meningkatkan kinerja keuangan karena terdorong untuk selalu bekerja secara efektif, efesien dan produktif. Hasil studi tersebut berlawanan dengan hasil penelitian Arifai dan Abral (2013) menunjukan bahwa sumber daya manusia tidak mempunyai pengaruh terhadap kinerja keuangan artinya tinggi rendahnya kualitas sumber daya manusia tidak berkaitan dengan tinggi rendahnya kinerja keuangan.

Hasil penelitian Kenis (1979), Qi (2010), Silva dan Jayamaha (2012) karakteristik anggaran (perencanaan anggaran, pengendalian anggaran, kecanggihan anggaran, partisipasi anggaran, kejelasan sasaran anggaran, evaluasi anggaran dan kesulitan sasaran anggaran) berpengaruh positif signifikan terhadap kinerja keuangan. Kualitas anggaran menjadi salah satu hal yang penting dalam menjamin terlaksananya program dan kegiatan suatu organisasi yang ekonomi, efektif dan efisien. Hal ini merupakan syarat utama tercapainya tujuan dan sasaran sebuah organisasi, maka dapat disimpulkan bahwa seberapa baik pencapaian tujuan dan sasaran suatu organisasi akan tergantung pada seberapa baik kualitas anggarannya. Sebaliknya penelitian Bangun (2009) dan Ramandei (2009) mengatakan tidak terdapat hubungan yang signifikan antara kejelasan sasaran anggaran terhadap kinerja instansi pemerintah.

Faktor keberhasilan peningkatan kinerja keuangan dalam pemberdayaan relasional kualitas sumberdaya manusia dan kualitas anggaran juga mesti didukung dengan pemanfaatan informasi dan teknologi yang memadai. Dengan memanfaatkan teknologi informasi, akses terhadap proses kegiatan organisasi dapat dilakukan dengan cepat sehingga pengambilan keputusan dapat dilakukan secara lebih cepat dan akurat dan pada akhirnya tujuan organisasi dapat tercapai. Oleh 
karena itu pemerintah sudah mulai mengembangkan dan memberi perhatian khusus pada tekonologi informasi sebagai sumber yang memfasilitasi pengumpulan dan penggunaan informasi secara efektif dan efisien.

Berkaitan dengan kinerja keuangan pemerintah di Kabupaten Buton Utara, Kepala Badan Pemeriksa Keuangan (BPK) RI Perwakilan Sultra, Nelson Ambarita pada Media Workshop pernah mengungkapkan bahwa dari ikhtisar Laporan Hasil Pemeriksaan (LHP) tahun 2010, 2011 dan 2012 terhadap Laporan Keuangan Pemerintah Daerah (LKPD) Kabupaten Buton Utara mendapat opini disclaimer atau Tidak Memberi pendapat (TMP) dan tahun 2013 mendapat opini Wajar Dengan Pengecualian (WDP) oleh Badan Pemeriksaan Keuangan (BPK) yang disebabkan permasalahan pengelolaan asset dan pengelolaan anggaran yang tidak sesuai undang-undang pengelolaan keuangan daerah. (http://www.kendari. bpk.go.id) dan (Antaranews.com, 2011). Hal ini mengambarkan kinerja keuangan di Kabupaten Buton Utara masih menghadapi masalah. Padahal menurut Peraturan Menteri Dalam Negeri Nomor 13 Tahun 2006 dalam pasal (4) bahwa keuangan daerah dikelola secara tertib, taat pada peraturan perundang-undangan yang efektif, efisien, ekonomis, transparan dan bertanggung jawab dengan memperhatikan azas keadilan, kepatuhan, dan manfaat untuk masyarakat. Oleh karena itu Sistem Informasi Manajemen Daerah (SIMDA) mengharapkan kinerja keuangan yang lebih baik dari tahun sebelumnya.

Berdasarkan research gap dan fenomena yang terjadi, maka hal tersebut menjadi alasan peneliti melakukan penelitian dengan judul "Peningkatan Kinerja Keuangan Daerah dalam Konteks Pemanfaatan Sistem Informasi Manajemen Daerah (SIMDA) pada SKPD Kabupaten Buton Utara.

\section{KAJIAN PUSTAKA}

\section{Kinerja Keuangan Daerah}

Kinerja keuangan daerah adalah gambaran tingkat pencapaian dari hasil kerja yang telah dilakukan dibidang keuangan daerah dengan menggunakan indikator yang telah diatur dalam perundang-undangan selama satu periode anggaran guna mendukung berjalannya sistem pemerintahan, pelayanan kepada masyarakat dan pembangunan daerah sesuai dengan visi dan misi daerahnya.

Menurut Mardiasmo (2009) menyatakan bahwa Value for money merupakan inti pengukuran kinerja keuangan pada unit-unit kerja pemerintah, dimana indikator value for money sebaikanya memusatkan perhatian pada pertanyaan mengenai ekonomis, efisiensi, dan efektifitas program dan kegiatan.

\section{Kualitas Sumber Daya Manusia}

Pengelolaan keuangan daerah yang baik, SKPD harus memiliki sumber daya manusia yang berkualitas, yang didukung dengan latar belakang pendidikan, sering mengikuti pendidikan dan pelatihan, dan mempunyai pengalaman di bidang keuangan (Wansyah, et.al, 2012). Hal ini sesuai dengan yang ditegaskan oleh Kesuma, et.al (2014) bahwa sumber daya manusia yang tepatlah yang akan menjadi aset berharga dalam organisasi. Collins menilai bahwa dalam suatu organisasi hal pertama dan utama yang harus diperhatikan adalah orangnya, setelah itu baru membahas visi, misi, strategi atau hal-hal lainnya yang diperlukan.

Berdasarkan penelitian yang dilakukan oleh Kamukama, et al (2010) mengatakan bahwa human capital (pendidikan, pengalaman, keterampilan, kreatifitas) berpengaruh secara positif signifikan terhadap kinerja keuangan 
lembaga keuangan mikro di Uganda. Penelitian ini serupa dengan Warisno (2009), Bakotic \& Buble (2011) menunjukan bahwa kualitas sumber daya manusia berpengaruh positif signifikant terhadap kinerja keuangan, dimana semakin tinggi kualitas sumber daya manusia maka kinerja keuangan juga akan meningkat. Berdasarkan uraian diatas maka hipotesis yang akan diuji adalah Kualitas sumber daya manusia berpengaruh signifikan terhadap kinerja keuangan daerah.

\section{Kualitas Anggaran}

Anggaran menjadi sangat penting di Pemerintah Daerah karena anggaran berdampak terhadap kinerja pemerintah yang berkaitan dengan fungsi pemerintah dalam memberi pelayanan kepada masyarakat. Menurut Kenis (1979) karakteristik anggaran yaitu partisipasi anggaran (budgetary participation), kejelasan sasaran anggaran (budget goal clarity), umpan balik anggaran (budgetary feedback), evaluasi anggaran. Menurut Qi (2010) indikator dari anggaran adalah perencanaan anggaran, pengendalian anggaran, kecanggihan anggaran, partisipasi anggaran, kejelasan sasaran anggaran, dan kesulitan sasaran anggaran.

Hasil penelitian Qi (2010), Silva dan Jayamaha (2012) membuktikan bahwa proses anggaran berpengaruh positif signifikant terhadap kinerja keuangan, dimana semakin baik proses anggaran suatu organisasi maka dapat meningkatkan kinerja keuangan suatu organisasi. Berdasarkan uraian diatas maka hipotesis yang akan diuji adalah $\mathrm{H} 2$ Kualitas anggaran berpengaruh signifikan terhadap kinerja keuangan daerah.

\section{Sistem Informasi Manajemen Daerah (SIMDA)}

Sistem Informasi Manajemen Daerah (SIMDA) sebagai aplikasi yang dikembangkan oleh Badan Pengawasan Keuangan dan Pembangunan (BPKP), dimana tujuan dari pengembangan aplikasi ini adalah untuk mempercepat proses reformasi pengelolaan keuangan daerah. Hal ini dilatarbelakangi oleh langkanya sumber daya manusia di pemerintahan daerah yang memiliki latar belakang pendidikan akuntansi, sehingga pemerintah daerah mengalami kesulitan dalam menyusun laporan keuangan sesuai dengan peraturan perundang-undangan yang berlaku sehingga bisa menghambat pengambilan keputusan dalam suatu organisasi.

Berdasarkan PP No. 56 Tahun 2005 tentang Sistem Informasi Keuangan Daerah, pemerintah daerah berkewajiban mengembangkan dan memanfaatkan kemajuan teknologi informasi untuk mempermudah dan mempercepat proses pengelolaan dan pelaporan keuangan guna pengambilan keputusan dalam suatu organisasi. Oleh karena itu, program aplikasi sistem informasi manajemen sangatlah dibutuhkan oleh pemerintah daerah karena bisa meningkatikan kinerja keuangan (Hashim, et.al, 2012). Mardjiono (2009) juga menyimpulkan bahwa pemanfaatan Teknologi Informasi berpengaruh terhadap Kinerja Instansi Pemerintah. Sehingga hipotesis dalam penelitian ini adalah Sistem Informasi Manajemen Daerah (SIMDA) berpengaruh signifikan memoderasi kualitas sumber daya manusia terhadap kinerja keuangan daerah.

Program aplikasi yang dimakud adalah Program Aplikasi Sistem Informasi Manajemen Daerah (SIMDA) dimaksudkan untuk membantu pengelolaan keuangan Satuan Kerja Perangkat Daerah (SKPD). Program ini diharapkan dapat memberikan manfaat kepada Pemerintah Daerah terutama dalam penyusunan Anggaran Pendapatan Belanja Daerah (APBD). Sistem informasi manajemen daerah (SIMDA) mempunyai tujuan diantaranya untuk membantu Kepala Daerah dan instansi terkait lainnya dalam melakukan evaluasi kinerja keuangan daerah. 
Hasil penelitian Nugraha dan Astuti (2013) mengatakan bahwa prosedur anggaran Satuan Kerja Perangkat Daerah (SKPD) setiap tahun dibantu dengan menggunakan aplikasi Sistem Informasi Manajemen Daerah (SIMDA) yang akurat, cepat, tepat waktu sehingga menghasilkan anggaran yang berkualitas yang berakibat terhadap pengambilan keputusan manajemen. Berdasarkan uraian di atas maka hipotesis yang akan diuji adalah Sistem Informasi Manajemen Daerah (SIMDA) berpengaruh signifikan memoderasi kualitas anggaran terhadap kinerja keuangan daerah.

\section{METODE}

Jenis penelitian ini adalah explanatory research yang bersifat menjelaskan dan bertujuan untuk menguji suatu teori atau hipotesis guna memperkuat atau bahkan menolak teori atau hipotesis hasil penelitian yang sudah ada Populasi dalam penelitian ini adalah seluruh Satuan Kerja Perangkat Daerah (SKPD) yang ada di Kabupaten Buton Utara yang berjumlah 34 SKPD.

Teknik pengambilan sampel dalam penelitian ini adalah adalah teknik sensus yaitu mengambil keseluruhan populasi sebagai responden penelitian sehingga jumlah sampel dalam penelitian ini adalah seluruh Satuan Kerja Perangkat Daerah (SKPD) yang ada di Kabupaten Buton Utara yang berjumlah 34 SKPD.

Dalam penelitihan ini pengumpulan data yang dilakukan adalah penyebaran kuesioner yang merupakan pengumpulan data secara langsung yang dilakukan dengan mengajukan daftar pertanyaan pada responden. Kuesioner diserahkan secara langsung pada responden yang disimpan dalam amplop dan dikembalikan dalam amplop tertutup untuk menjaga kerahasiaanya.

Teknik analisis yang digunakan dalam penelitian ini menggunakan konsep Struktural Equatin Model (SEM) dengan program Partial Least Square (PLS). Analisis Partial Least Square (PLS) adalah metode analisis yang powerful oleh karena tidak mengasumsikan data harus dengan pengukuran skala tertentu, dapat diterapkan pada semua skala, tidak membutuhkan banyak asumsi dan ukuran sampel tidak harus besar (Ghozali, 2011)

Tabel 1.1. Devenisis Operasional dan IndIkator

\begin{tabular}{|c|c|c|}
\hline Variabel & Indikator & Sumber \\
\hline Kualitas Sumber Daya Manusia & $\begin{array}{l}\text { - } \quad \text { Latar Belakang Pendidikan } \\
\text { - } \quad \text { Mengikuti Pendidikan/ } \\
\text { Pelatihan } \\
\text { - }\end{array}$ & $\begin{array}{l}\text { Gomes,et.al } \\
\text { 2013,Wansyah, } \\
\text { et.al, } 2012\end{array}$ \\
\hline Kualitas Anggaran & $\begin{array}{ll}\text { - } & \text { Perencanaan Anggaran } \\
\text { - } & \text { Kejelasan Sasaran Anggaran } \\
\text { - } & \text { Evaluasi Anggaran }\end{array}$ & $\begin{array}{l}\text { Qi } 2010 \text { dan Silva \& } \\
\text { Jayamaha, } \\
2012\end{array}$ \\
\hline Kinerja Keuangan Daerah & $\begin{array}{ll}\text { - } & \text { Ekonomis } \\
\text { - } & \text { Efisien } \\
\text { - } & \text { Efektif }\end{array}$ & Mardiasmo (2009) \\
\hline $\begin{array}{l}\text { Sistem Informasi } \quad \text { Manajemen } \\
\text { Daerah (SIMDA) }\end{array}$ & $\begin{array}{ll}\text { - } & \text { Akurat } \\
\text { - } & \text { Keberhasilan } \\
\text { - } & \text { Kemanfaatan }\end{array}$ & $\begin{array}{l}\text { Nugraha \& Astuti, } \\
2013 \text { dan Budiman } \\
\text { \& Arza, } 2013\end{array}$ \\
\hline
\end{tabular}




\section{HASIL DAN PEMBAHASAN}

\section{Hasil Inner Model}

Hasil pengujian inner model terhadap nilai $R$-square konstruk kinerja keuangan menjadi faktor penentu variabel kualitas SDM dan kualitas anggaran sebesar 0.815 atau sebesar $81,5 \%$ artinya bahwa $81,5 \%$ variasi kinerja keuangan dapat dijelaskan oleh kualitas sumber daya manusia dan kualitas anggaran sedangkan sisanya $18,5 \%$ ditentukan variabel lain yang tidak termasuk dalam model penelitian.

Tabel 1.2. result for inner weight

\begin{tabular}{ccccc}
\hline Variable & $\begin{array}{c}\text { Original } \\
\text { Sample }\end{array}$ & Sample Mean & $\begin{array}{c}\text { Standard } \\
\text { deviation }\end{array}$ & T-Statistic \\
\hline KSDM-> KK & 0.390 & 0.430 & 0.176 & 2.212 \\
KA -> KK & 0.767 & 0.774 & 0.356 & 2.154 \\
KSDM*SIMDA - & 1.139 & 1.091 & 0.356 & 3.199 \\
$\begin{array}{c}\text { >KK } \\
\text { KA*SIMDA->KK }\end{array}$ & 1.494 & 1.466 & 0.521 & 2.868 \\
\hline
\end{tabular}

\section{Hasil Pengujian Hipotesis}

Hipotesis 1 dalam penelitian ini adalah kualitas sumber daya manusia berpengaruh signifikan terhadap kinerja keuangan daerah. Nilai original sample estimate menunjukan angka positif sebesar 0.390 dengan nilai t-statistik 2.212 lebih besar dari t-tabel $1.694(\alpha=0.05 \mathrm{dan} \mathrm{df}=32)$ atau t-statistik (2.212) > t-tabel (1.694) sehingga nilai tersebut menunjukkan ada pengaruh positif signifikan antara kualitas sumber daya manusia terhadap kinerja keuangan daerah maka dapat disimpulkan bahwa hipotesis pertama yang diajukan dalam penelitian ini "kualitas sumber daya manusia berpengaruh signifikan terhadap kinerja keuangan daerah "diterima.

Hipotesis 2 dalam penelitian ini adalah kualitas anggaran berpengaruh signifikan terhadap kinerja keuangan daerah. Nilai original sample estimate menunjukan angka positif yaitu 0.767 dengan nilai t-statistik 2.154 lebih besar dari t-tabel $1.694(\alpha=0.05$ dan $\mathrm{df}=32)$ atau t-statistik (2.154) > t-tabel (1.694) sehingga nilai tersebut menunjukkan ada pengaruh positif signifikan antara kualitas anggaran terhadap kinerja keuangan daerah maka dapat disimpulkan bahwa hipotesis kedua yang diajukan dalam penelitian ini "kualitas anggaran berpengaruh signifikan terhadap kinerja keuangan daerah "diterima.

Hipotesis 3 dalam penelitian ini adalah Sistem Informasi Manajemen Daerah (SIMDA) berpengaruh signifikan memoderasi kualitas sumber daya manusia terhadap kinerja keuangan daerah. Nilai original sample estimate menunjukan angka positif yaitu 1.139 dengan nilai t-statistik 3.199 lebih besar dari t-tabel $1.694(\alpha=0,05$ dan $\mathrm{df}=32)$ atau t-statistik (3.199) > t-tabel (1.694) sehingga nilai tersebut menunjukkan ada pengaruh positif signifikan antara kualitas sumber daya manusia terhadap kinerja keuangan daerah ketika di moderating oleh Sistem Informasi Manajemen Daerah (SIMDA) maka dapat disimpulkan hipotesis bahwa hipotesis ketiga yang diajukan dalam penelitian ini "Sistem Informasi Manajemen Daerah (SIMDA) berpengaruh signifikan memoderasi kualitas sumber daya manusia terhadap kinerja keuangan daerah "diterima, artinya bahwa Sistem Informasi Manajemen Daerah (SIMDA) "memperkuat" pengaruh kualitas sumber daya manusia terhadap kinerja keuangan daerah. 
Hipotesis 4 dalam penelitian ini adalah Sistem Informasi Manajemen Daerah (SIMDA) berpengaruh signifikan memoderasi kualitas sumber daya manusia terhadap kinerja keuangan daerah. Nilai original sample estimate menunjukan angka positif yaitu 1.494 dengan nilai t-statistik 2.868 lebih besar dari t-tabel $1.694(\alpha=0.05 \mathrm{dan} \mathrm{df}=32)$ atau t-statistik (2.868) $>$ t-tabel (1.694) sehingga nilai tersebut menunjukkan ada pengaruh positif signifikan antara kualitas anggaran terhadap kinerja keuangan daerah ketika di moderating oleh Sistem Informasi Manajemen Daerah (SIMDA) maka dapat disimpulkan bahwa hipotesis keempat yang diajukan dalam penelitian ini "Sistem Informasi Manajemen Daerah (SIMDA) berpengaruh signifikan memoderasi kualitas anggaran terhadap kinerja keuangan daerah "diterima, artinya bahwa Sistem Informasi Manajemen Daerah (SIMDA) "memperkuat" pengaruh kualitas anggaran terhadap kinerja keuangan daerah.

\section{Pengaruh Kualitas Sumber Daya Manusia terhadap Kinerja Keuangan Daerah}

Berdasarkan hasil penelitian diperoleh bahwa kualitas sumber daya manusia berpengaruh positif signifikan terhadap kinerja keuangan daerah. Hal ini disebabkan pentingnya kualitas sumber daya manusia pada Satuan Kerja Perangkat Daerah (SKPD) Kabupaten Buton Utara baik berupa latar belakang pendidikan, mengikuti pendidikan/pelatihan dan pengalaman merupakan faktor penting dalam meningkatkan kinerja keuangan daerah secara ekonomis, efisien, dan efektif. Faktor terpenting dan paling menentukan adalah pengalaman yang ditunjukkan dengan loading faktor tertinggi. Hal ini menunjukan bahwa dengan adanya pengalaman yang dimiliki oleh pengelola keuangan Satuan Kerja Perangkat daerah (SKPD) maka akan mengurangi tingkat kesalahan dalam menyelesaikan pekerjaan sehingga akan meningkatkan kinerja keuangan yang efisien dengan tujuan untuk mencapai kesejahteraan masyarakat. Kondisi ini memberikan gambaran bahwa kualitas sumber daya manusia mempunyai peran penting dalam peningkatan kinerja keuangan daerah pada SKPD yang ada di Kabupaten Buton Utara.

Warisno, (2009) yang mengatakan bahwa Sumber daya manusia adalah salah satu elemen organisasi yang sangat penting, oleh karena itu harus dipastikan bahwa pengelolaan sumber daya manusia dilakukan sebaik mungkin agar mampu memberikan kontribusi secara optimal dalam upaya pencapaian tujuan organisasi. Hasil penelitian ini mendukung penelitian dari Sung, et.al (2011), Gomes, et.al (2013) menunjukkan bahwa kualitas sumber daya manusia berpengaruh positif signifikan terhadap kinerja keuangan.

\section{Pengaruh Kualitas Anggaran Terhadap Kinerja Keuangan Daerah}

Berdasarkan hasil penelitian dan pengujian pada hipotesis diperoleh bahwa kualitas anggaran berpengaruh positif signifikan terhadap kinerja keuangan daerah. Hal ini disebabkan pentingnya kualitas anggaran pada Satuan Kerja Perangkat Daerah (SKPD) Kabupaten Buton Utara baik berupa perencanaan anggaran, kejelasan sasaran anggaran, dan evaluasi anggaran merupakan faktor penting dalam meningkatkan kinerja keuangan daerah secara ekonomis, efisien, dan efektif. Faktor terpenting dan paling menentukan adalah evaluasi anggaran yang ditunjukkan dengan loading faktor tertinggi. Hal ini menunjukan bahwa evaluasi anggaran yang dilakukan secara optimal akan menghindari terjadi penyimpangan dan kecurangan dalam pengeloaan keuangan daerah sehingga akan meningkatkan kinerja keuangan yang efisien dengan tujuan untuk mencapai kesejahteraan masyarakat. 
Hasil penelitian ini mengindikasikan bahwa tinggi dan rendahnya kualitas anggaran akan mempengaruhi tinggi dan rendahnya kinerja keuangan, dengan kata lain apabila kualitas anggaran tinggi maka kinerja keuangan akan meningkat sebaliknya apabila kualitas anggaran rendah maka kinerja keuangan juga rendah..

Hasil penelitian ini mendukung penelitian dari Qi (2010), Silva dan Jayamaha (2012) menunjukkan bahwa kualitas anggaran berpengaruh positif signifikan terhadap kinerja keuangan. Hal ini menunjukan bahwa semakin tinggi kualitas anggaran (perencanaan anggaran, kejelasan sasaran anggaran dan evaluasi anggaran) maka akan tercapai kinerja keuangan yang baik. Dengan demikian, yang harus dilakukan oleh setiap Satuan Kerja Perangkat Daerah adalah memaksimalkan kualitas anggaran melalui perencanaan anggaran yang optimal di setiap SKPD, menggambarkan sasaran yang jelas agar dimengerti oleh yang bertanggung jawab atas pencapaian sasaran anggaran tersebut, serta melakukan evaluasi anggaran agar tidak terjadi penyimpangan sehingga akan menghasilkan kinerja keuangan yang baik.

\section{Pengaruh Sistem Informasi Manajemen Daerah (SIMDA) Memoderasi} Kualitas Sumber Daya Manusia Terhadap Kinerja Keuangan Daerah

Berdasarkan hasil penelitian dan pengujian pada hipotesis diperoleh bahwa ada pengaruh positif signifikan antara kualitas sumber daya manusia terhadap kinerja keuangan daerah ketika di moderating oleh Sistem Informasi Manajemen Daerah (SIMDA). Hal ini berarti bahwa Sistem Informasi Manajemen Daerah (SIMDA) "memperkuat" pengaruh kualitas sumber daya manusia terhadap kinerja keuangan daerah. Hal ini disebabkan pentingnya Sistem Informasi manajemen Daerah (SIMDA) pada Satuan Kerja Perangkat Daerah (SKPD) Kabupaten Buton Utara dalam pengelolaan keuangan dimana Sistem Informasi Manajemen Daerah (SIMDA) dapat menghasilkan informasi yang akurat, membantu keberhasilan pengelolaan keuangan, serta memiliki kemanfaatan yang baik dalam memproses data sehingga dapat menciptakan tata kelola keuangan secara ekonomis, efisien dan efektif bila dibandingkan dengan cara manual.

Hasil penelitian ini mengindikasikan bahwa semakin baik pemanfaatan SIMDA maka memperkuat pengaruh kualitas sumber daya manusia dalam meningkatkan kinerja keuangan daerah. Hasil penelitian ini mendukung penelitian dari Budiman dan Arza (2013) yang menyatakan bahwa dengan menggunakan aplikasi SIMDA secara benar dapat membantu peningkatan kinerja dan kualitas kerja dari pegawai SKPD kearah lebih baik serta mempercepat pekerjaan sehingga pekerjaan lebih efektif. Dengan demikian, yang harus dilakukan oleh setiap Satuan Kerja Perangkat Daerah adalah memaksimalkan pemanfaatan Sistem Informasi Manajemen Daerah (SIMDA) agar bisa membantu pengelola keuangan dalam mengelola keuangan setiap SKPD sehingga tercapai kinerja keuangan yang baik.

\section{Pengaruh Sistem Informasi Manajemen Daerah (SIMDA) Memoderasi Kualitas Anggaran Terhadap Kinerja Keuangan Daerah}

Berdasarkan hasil penelitian dan pengujian pada hipotesis diperoleh bahwa ada pengaruh positif signifikan antara kualitas anggaran terhadap kinerja keuangan daerah ketika di moderating oleh Sistem Informasi Manajemen Daerah (SIMDA). Hal ini berarti bahwa Sistem Informasi Manajemen Daerah (SIMDA) "memperkuat" pengaruh kualitas anggaran terhadap kinerja keuangan daerah. Hal ini disebabkan pentingnya Sistem Informasi manajemen Daerah (SIMDA) pada Satuan Kerja Perangkat Daerah (SKPD) Kabupaten Buton Utara dalam 
penganggaran dimana Sistem Informasi Manajemen Daerah (SIMDA) dapat menghasilkan informasi yang akurat, membantu keberhasilan pengelolaan keuangan, serta memiliki kemanfaatan yang baik dalam memproses data sehingga dapat menciptakan tata kelola keuangan secara ekonomis, efisien dan efektif bila dibandingkan dengan cara manual. Kondisi ini memberikan gambaran bahwa Sistem Informasi Manajemen Daerah (SIMDA) mempunyai peran penting dalam memperkuat pengaruh kualitas anggaran dalam upaya peningkatan kinerja keuangan daerah di Kabupaten Buton Utara.

Hasil penelitian ini mengindikasikan bahwa semakin baik pemanfaatan SIMDA maka memperkuat kualitas anggaran dalam meningkatkan kinerja keuangan daerah. Hal ini sesuai dengan penelitian yang dilakukan oleh Sudaryanti (2013) mengungkapkan bahwa Sistem Informasi Manajemen Daerah (SIMDA) merupakan sarana untuk membantu kegiatan pengelolaan keuangan daerah yang mencakup kegiatan penganggaran, penatausahaan keuangan. Hasil penelitian ini mendukung penelitian dari Sudaryanti (2013) bahwa penganggaran berpengaruh positif signifikan terhadap kinerja melalui sistem informasi keuangan daerah.

\section{KESIMPULAN}

Kualitas sumber daya manusia berpengaruh positif signifikan terhadap kinerja keuangan daerah. Oleh karena itu, untuk meningkatkan kinerja keuangan daerah dapat dilakukan dengan meningkatkan kualitas sumber daya manusia, dengan faktor terpenting dan paling menentukan adalah pengalaman. Dengan adanya pengalaman pengelola keuangan Satuan Kerja Perangkat daerah (SKPD) yang semakin baik maka akan mengurangi tingkat kesalahan dalam menyelesaikan pekerjaan sehingga akan meningkatkan kinerja keuangan yang efisien.

Kualitas anggaran berpengaruh positif signifikan terhadap kinerja keuangan daerah. Oleh karena itu, untuk meningkatkan kinerja keuangan daerah dapat dilakukan dengan meningkatkan kualitas anggaran, dengan faktor terpenting dan paling menentukan adalah evaluasi anggaran.

Sistem Informasi Manajemen Daerah (SIMDA) berpengaruh positif signifikan dalam memoderasi kualitas sumber daya manusia terhadap kinerja keuangan daerah. Artinya Sistem Informasi Manajemen Daerah (SIMDA) "memperkuat" pengaruh kualitas sumber daya manusia terhadap kinerja keuangan daerah.

Sistem Informasi Manajemen Daerah (SIMDA) berpengaruh positif signifikan dalam memoderasi kualitas anggaran terhadap kinerja keuangan daerah. Artinya Sistem Informasi Manajemen Daerah (SIMDA) "memperkuat" pengaruh kualitas anggaran terhadap kinerja keuangan daerah.

\section{Implikasi Manajerial}

Untuk setiap Satuan Kerja Perangkat Daerah (SKPD) Kabupaten Buton Utara agar pengelola keuangan daerah diutamakan sumber daya manusia yang berpengalaman karena akan mengurangi tingkat kesalahan dalam menyelesaikan pekerjaan. Serta evaluasi anggaran harus dilakukan secara optimal agar menghindari terjadi penyimpangan dan kecurangan yang dilakukan oleh pengelola keuangan sehingga berdampak terhadap peningkatan kinerja keuangan secara ekonomis, efektif, dan efisien. 


\section{DAFTAR RUJUKAN}

Antaranews.Com.,2011. Dua Kabupaten Sultra "Disclaimer" Selama Tiga Tahun. http://www.antarasultra.com/print/269174/dua-kabupaten-sultradisclaimer-selama-tiga-tahun. Diakses tanggal 05 Desember 2014.

Arifai, Muhammad dan Abral, Edi. 2013. Faktor yang mempengaruhi Implementasi Kinerja Keuangan Pemerintah Daerah. Jurnal Ekonomi dan Bisnis. Dosen Jurusan Tata Niaga Politeknik Negeri Lhokseumawe Vol.14, No.1: 1-9.

Bakotic, Danica \& Buble, Marin. 2011. Relationship between Knowledge Workers' Participation and Organizational Performance. Ekonomska istraživanja, Vol. 24, No. 3: 115-130.

Bangun, Andarias. 2009. Pengaruh Partisipasi Dalam Penyusunan Anggaran, Kejelasan Sasaran Anggaran dan Struktur Desentralisasi Terhadap Kinerja Manajerial SKPD dengan Pengawasan Internal Sebagai Variabel Pemoderasi (Studi Kasus Pada Pemerintah Kabupaten Deli Serdang. Tesis S2 Program Pasca Sarjana Universitas Sumatera Utara Medan.

Budiman, Fuad dan Arza, Fefri Indra. 2013. Pendekatan Technology Acceptance Model Dalam Kesuksesan Implementasi Sistem Informasi Manajamen Daerah. Jurnal WRA, Vol. 1, No. 1: 87-110.

Ghozali, Imam. 2008. Structural Equation Modeling Metode Alternatif dengan Partial Least Square. Semarang: Badan Penerbit Universitas Diponegoro.

Gomes, Ricardo C., Alfinito, S., Albuquerque, Pedro H.M. 2013. Analyzing Local Government Financial Performance: Evidence from Brazilian Municipalities 2005-2008. RAC, Rio de Janeiro, Vol. 17, No. 6: 704-719.

Greiling, Dorothea. 2005. Performance Measurement in the Public Sector: The German Experience. International Journal of Productivity and Performance Managemen. Vol. 54, No.7:551-567.

Hashim, M., Yousaf, A., Jehangir, M., dan Khan, S. 2012. The Impact of Management Information System on the Overall Performance and Efficiency of the Workforce of the Accountant General (Peshawar): A Research Base Study. International Journal of Academic Research in Accounting, Finance and Management Sciences Vol. 2, Issue 2: 167-182.

Kamukama, N., Ahiauzu, A., dan Josep (2010). "Intellectual Capital And Financial Performance In Uganda's Microfinance Institutions." African Journal of Accounting, Economics, Finance and Banking Research 6(6): 17-31.

Kesuma, I., Nadirsyah, dan Darwanis. 2014. Pengaruh Kompetensi Sumber Daya Manusia, Peran Internal Auditor dan Aktivitas Pengendalian Terhadap Nilai Informasi Pelaporan Keuangan Pemerintah Daerah (Studi Pada Pemerintah Kabupaten Aceh Utara). Jurnal Akuntansi Pascasarjana Universitas Syiah Kuala Banda Aceh. Vol 3, No. 1: 73- 82.

Kennis. 1979. Effect on Budgentary Good Characteristic on Managerial Attitude and Performance. The Accounting Review.

Mardjiono, Didik Eko. (2009). Analisis Pengaruh Kepemimpinan, Pemanfataan TI dan Implementasi Struktur Organisasi yang Terdesentralisasi Terhadap Kinerja Organisasi (Studi pada RSUD Kab. Temanggung. Tesis Universitas Padjajaran Bandung.

Mardiasmo. 2009. Akuntansi Sektor Publik. Edisi ke-4. Yogyakarta: Andi.

Nordiawan, Deddi. 2008. Akuntansi Sektor Publik. Edisi 1. Jakarta: Salemba Empat. 
Nugraha, Harmadhani Adi dan Astuti, Yuli Widi. 2013. Analisis Penerapan Sistem Informasi Manajemen Keuangan Daerah (SIMDA) Keuangan Dalam Pengolahan Data Keuangan Pada Organisasi Pemerintah Daerah (Studi Kasus Pada Dinas Kesehatan Kabupaten Nganjuk). Jurnal Akuntansi Aktual, Vol. 2, No. 1: 25-33.

Qi, Yang. 2010. The Impact of the Budgeting Process on Performance in Small and Medium-Sized Firms in China. Dissertation University of Twente

Ramandei, Pilipus. 2009. Pengaruh karakteristik sasaran anggaran dan Sistem Pengendalian Intern terhadap Kinerja Manajerial Aparat Pemerintah Daerah (Studi Empiris pada Satuan Kerja Perangkat Daerah Kota Jayapura). Tesis S2 Program Pascasarjana Universitas Diponegoro Semarang.

Silva, L.M.D dan Jayamaha, Ariyarathna. 2012. Budgetary Process and Organizational Performance of Apparel Industry in Sri Lanka. Journal of Emerging Trends in Economics and Management Sciences (JETEMS). Vol.3, No.4.

Sitti Dharma, 2015. Peningkatan Kinerja Keuangan Daerah Dalam Konteks Pemanfaatan Sistem Informasi Manajemen Daerah (Simda) Pada Skpd Kabupaten Buton Utara. Tesis. Magister Manajemen.Universitas Islam Sultan Agung Semarang

Sudaryanti. 2013. Pengaruh Penganggaran Terhadap Kinerja Aparat Pemda Melalui Sistem Informasi Keuangan Daerah (Studi Kasus: Pemda Kab. Kudus). Jurnal Ekonomi dan Bisnis. Vol. 12, No. 01: 11-24.

Sung, Y., Sun, Choi dan Nam, J. 2011. The Effects of Human Resource Development on Operational and Financial Performance of Manufacturing Companies: a large-scale, Longitudinal Analysis. Institute for Research on Labor and Employment.

Wansyah, H., Darwanis dan Bakar, Usman. 2012. Pengaruh Kapasitas Sumber Daya Manusia, Pemanfaatan Teknologi Informasi dan Kegiatan Pengendalian Terhadap Nilai Informasi Pelaporan Keuangan SKPD pada Provinsi Aceh. Jurnal Akuntansi Pascasarjana Universitas Syiah Kuala Banda Aceh. Vol. 1, No. 1, hal: 43-58.

Warisno. 2009. Faktor-Faktor yang Mempengaruhi Kinerja Satuan Kerja Perangkat Daerah (SKPD) di Lingkungan Pemerintah Provinsi Jambi. Tesis S2 Program Pascasarjana Universitas Sumatera Utara Medan. Tesis. 